\title{
Rancang Bangun Sistem Informasi Perpustakaan Berbasis Mobile Pada Sekolah Tinggi Teknologi Dumai
}

\author{
Sigit Setiyanto', Wing Wahyu Winarno², Armadyah Amborowati ${ }^{3}$ \\ 1,2,3MagisterTeknik Informatika, Universitas Amikom Yogyakarta \\ E-mail: 1sigitsiak@gmail.com, \\ ${ }^{2}$ wing@amikom.ac.id, ${ }_{2}^{3}$ armadyah.a@amikom.ac.id
}

\begin{abstract}
Abstrak
Perpustakaan merupakan tempat yang banyak digunakan mahasiswa untuk mencari informasi didalam memecahkan suatu masalah yang ditemui pada proses pembelajaran. Pemanfaatan teknologi aplikasi berbasis android sangat membantu perpustakaan dalam memberikan pelayanan sirkulasi perpustakaan yang cepat, akurat, real time dan up to date. Metode yang digunakan untuk rancang bangun prototype perancangan sistem informasi sirkulasi perpustakaan berbasis mobile menggunakan metode waterfall dan menggunakan pendekatan Structured Systems Analysis and Design Method (SSADM).

Algoritma yang digunakan pada proses pencarian pustaka melalui teks menggunakan algoritma boyer moore sehingga proses pencarian data akan menjadi lebih cepat. Pengujian dilakukan dalam rangka melakukan verifikasi dan validasi perangkat lunak. Proses verifikasi dilakukan dengan melakukan pengujian white box sedangkan proses validasi dilakukan dengan melakukan pengujian black box. Pengujian usabilitydigunakan untuk menentukan tingkat kegunaan dari sebuah aplikasi dan merupakan kunci keberhasilan sebuah produk dengan syarat penerimaan pengguna. Pengujian usability pada penelitian ini mencakup 4 aspek utama learnability, flexibility, effectiveness, dan attitude.

Penelitian yang dilakukan mampu menghasilkan perancangan sistem informasi perpustakaan berbasis mobileandroid menggunakan metode waterfall dengan pendekatan Structured System Analysis and Design Method (SSADM). Fitur yang ada pada sistem sangat memudahkan user dalam mendapatkan berbagai informasi mengenai pelayanan perpustakaan.
\end{abstract}

Kata Kunci- Perpustakaan, Structured Systems Analysis and Design Method, Mobile

Abstract
Library is a place that many students use to find information in solving a
problem encountered in the learning process. Utilization of android-based application
technology is very helpful in providing libraries library services in a fast, accurate,
real time and up to date. The method used to design prototype design of information
system of mobile library based circulation using waterfall method and using
Structured Systems Analysis and Design Method (SSADM) approach.
Algorithm used in literature search process through text using boyer moore
algorithm so that process of searching data will become faster. Testing is done in order
to verify and validate the software. The verification process is done by testing white
box while the validation process is done by testing black box.Usability testing is used
to determine the usefulness of an application and is the key to a product's success with
UNITEX Vol 11 No.1 Januari - Juni 2018
e-ISSN
p-ISSN 2089-
3957


the terms of user acceptance. The usability test in this research covers 4 main aspects of learnability, flexibility, effectiveness, and attitude.

The research is able to produce information system design of mobile android based library using waterfall method with Structured System Analysis and Design Method (SSADM) approach. Features that exist on the system greatly facilitate the user in obtaining various information about the library services.

Keywords - Library, Structured Systems Analysis and Design Method, Mobile

\section{PENDAHULUAN}

Kemajuan teknologi pada saat ini yang semakin pesat belum dimanfaatkan di Sekolah Tinggi Teknologi Dumai (STT Dumai). Contohnya dalam layanan perpustakaan khususnya dalam pelayanan sirkulasi perpustakaan di STT Dumai. Saat ini perpustakaan masih memakai sirkulasi secara manual dalam mencari pustaka di perpustakaan. Pada saat ini informasi mengenai sirkulasi perpustakaan hanya didapat mahasiswa dengan menanyakan langsung ataupun melakukan pencarian di perpustakaan saja. Mahasiswa yang bersifat mobile yang mempunyai banyak aktivitas di luar perpustakaan menemui permasalahan dalam mencari informasi koleksi perpustakaan. Oleh karena itu, dengan adanya sistem yang berbasis mobile aplikasi akan sangat membantu mahasiswa dalam memperoleh informasi koleksi perpustakaan dan tidak harus ke perpustakaan langsung.

Perpustakaan perguruan tinggi adalah unit penunjang bagi terselenggaranya tujuan perguruan tinggi, yaitu tri dharma perguruan tinggi yang terdiri dari pendidikan, penelitian dan pemberdayaan masyarakat. Katalog perpustakaan adalah suatu daftar yang sistematis dari buku dan bahan-bahan lain dalam suatu perpustakaan dengan informasi deskriptif mengenai pengarang, judul, penerbit, tahun terbit, bentuk fisik, subjek, ciri khas bahan dan tempatnya [1]. Kegiatan pelayanan perpustakaan dapat dilihat dari dua sisi, yaitu dari sisi penyedia layanan dan dari sisi pemakai layanan. Dari sisi penyedia layanan kegiatan pelayanan seperti pengadaan pustaka, penyiapan pustaka, pemberian pelayanan dan pemeliharaan pustaka. Dari sisi pengguna layanan terdapat beberapa kegiatan seperti mencari pustaka, membaca/memanfaatkan pustaka dan meminjam pustaka [2]. Metode waterfall adalah sebuah metode pengembangan software yang bersifat sekuensial dan terdiri dari 4 tahap yang saling terkait dan mempengaruhi. Berikut adalah tahap dalam model waterfall:analysis, design, code dan test[3]. Model air terjun (waterfall) kadang dinamakan siklus hidup klasik (classic life cycle), dimana hal ini menyiratan pendekatan yang sistematis dan berurutan (sekuensial) pada pengembangan perangkat lunak, yang dimulai dengan spesifikasi kebutuhan pengguna dan berlanjut melalui tahapan-tahapan perencanaan (planning), pemodelan (modeling), kontruksi (contruction), serta penyerahan sistem/perangkat lunak ke para pelanggan/pengguna (deployment), yang diakhiri dengan dukungan berkelanjutan pada perangkat lunak [4].

Structured System Analysis and Design Method (SSADM) merupakan suatu metodologi pendekatan sistem untuk analisis dan desain sistem informasi. Metodologi ini dikhususkan hanya untuk analisis dan perancangan dengan membaginya menjadi 5 modul utama, yaitu Feasibility Study, Requrements Analysis, Requirements Spesification, Logical System Specification, dan Physical Design [5]. Algoritma Boyer-Moore adalah salah satu dari pencarian string yang tepat dan terkenal algoritma pencocokan yang digunakan dalam pencocokan pola tunggal dan menganggap sangat cepat dalam kinerjanya. Dengan menggunakan algoritma ini, secara rata-rata proses pencarian akan menjadi lebih cepat jika dibandingkan 
dengan algoritma lainnya [6]. Usability adalah analisa kualitatif yang menentukan seberapa mudah user menggunakan antarmuka suatu aplikasi. Suatu aplikasi disebut usable jika fungsi-fungsinya dapat dijalankan secara efektif, efisien, dan memuaskan [7]. Pengujian usabilitas adalah proses yang bekerja dengan pengguna akhir secara langsung maupun tidak langsung untuk menilai bagaimana pengguna merasakan paket perangkat lunak dan bagaimana mereka berinteraksi dengannya. Tujuan dari pengujian usabilitas harus membatasi dan menghilangkan kesulitan bagi pengguna dan untuk memengaruhi area yang kuat untuk usabilitas maksimum. Pengujian ini idealnya melibatkan masukan dari pengguna secara langsung maupun tidak langsung (mengamati perilaku) dan bila memungkinkan melibatkan komputer yang didukung umpan balik [8]. Pengujian usability pada penelitian ini mencakup 4 aspek utama, yaitu Learnability, Flexibility, Effectiveness, dan Attitude.

\section{METODE PENELITIAN}

Metode penelitian yang digunakan untuk merancang sistem pada penelitian ini adalah menggunakan metode Waterfall dan untuk perancangan aplikasinya menggunakan pendekatan Structured System Analysis and Design Method (SSADM). Pengujian yang dilakukan menggunakan pengujian white box testing, black box testing, dan pengujian usability.

\section{Metode Pengumpulan Data}

Pengumpulan data yang digunakan dalam memperoleh data yang akan dibutuhkan dalam penyusunan penelitian ini adalah sebagai berikut:

a. Studi Literatur

Pada studi literatur digunakan peneliti untuk menemukan sumber riset dan informasi melalui media online maupun media cetak. Dalam studi literatur ini peneliti mencari dari berbagai sumber dan referensi terkait tentang metode penelitian waterfall, pendekatan SSADM, dan pengujian usability.

b. Metode Wawancara

Metode wawancara merupakan suatu metode pengumpulan data dengan mengajukan tanya jawab langsung kepada pihak terkait yang berkompeten dibidang permasalahan ini. Wawancara ini dilakukan untuk menemukan permasalahan yang ada pada sistem perpustakaan yang ada.

c. Metode Observasi

Metode obervasi atau pengamatan merupakan salah satu metode pengumpulan data atau fakta yang bertujuan untuk memperoleh informasi yang diperlukan dengan cara melakukan pengamatan dan pencatatan tentang permasalahan ada. Observasi ini dilakukan di Sekolah Tinggi Teknologi Dumai, pengamatan ditekankan pada sistem perpustakaan saat ini.

2. Instrumen Penelitian

Instrumen penelitian ini meliputi instrumen tahap feasibility study pada tahapan pendekatan SSADM dan instrumen tahap pengujian usability adalah sebagai berikut:

a. Instrumen Feasibility Study

Pada penelitian ini instrumen Feasibility Study merupakaninstrumen penentuan studi kelayakan pembangunan sebuah sistem informasi perpustakaan berbasis mobile smartphone. Terdapat beberapa intrumen pertanyaan yang diisi oleh responden untuk mengetahui kelayakan sistem 
sebelumnya. Indikator perlunya pengembangan sistem ditandai dengan penilaian sistem lama kurang dari $40 \%$ dan penilaian untuk pengembangan sistem baru lebih dari 40\%.

b. Instrumen Pengujian Usability

Instrumen pengujian usability pada penelitian ini dilakukan dengan metode kuisioner yang bertujuan untuk mengukur tingkat usability sistem informasi perpustakaan berbasis mobile di STT Dumai. Pengujian ini diukur dengan mencakup beberapa aspek usability, yaitu learnability, flexibility, effectiveness, dan attitude. Kuesioner diisi oleh para responden setelah mereka selesai menguji aplikasi untuk mendapatkan informasi mengenai perpustakaan.

3. Alur Penelitian

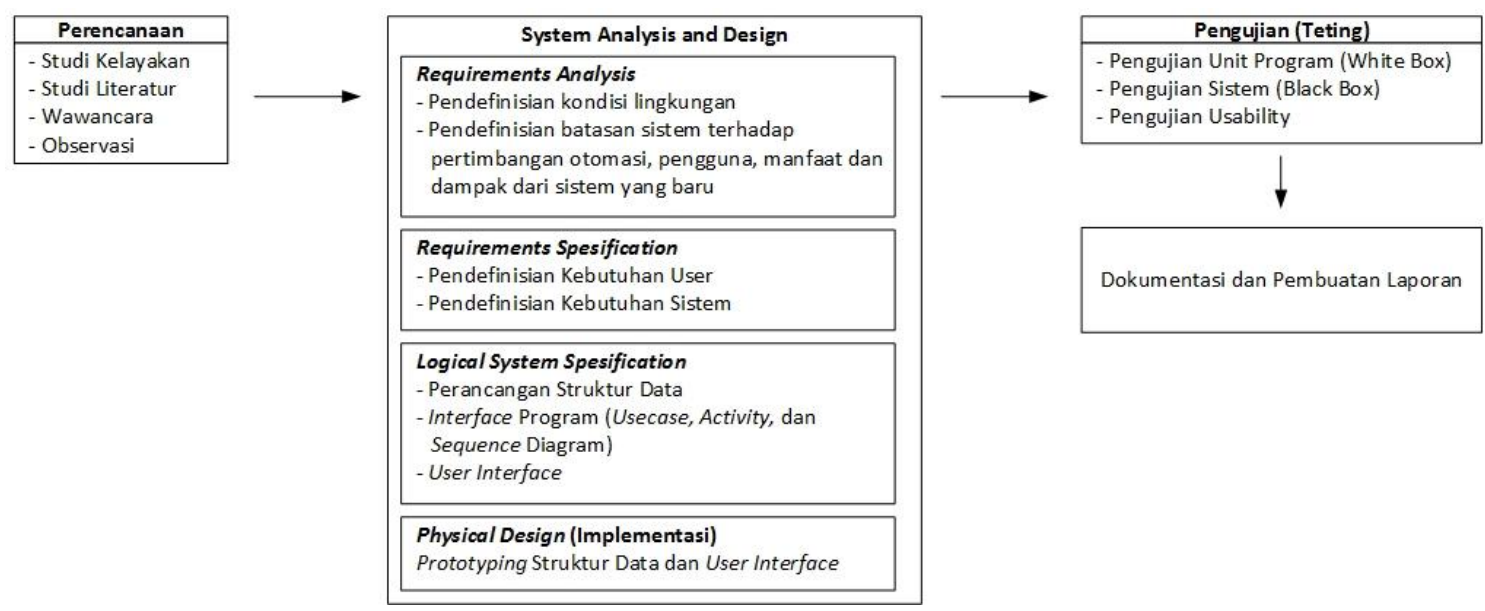

Gambar 1. Alur Penelitian

Gambar 1 diatas menunjukkan alur penelitian dimulai dari tahap perencanaan meliputi studi kelayakan (feasibilitystudy), studi literatur, waawancara dan observasi. Proses selanjutnya systemanalysisanddesign yang memiliki beberapa tahap yaitu requirements analysis, requirements specification, logical system specification, dan physical design. Langkah selanjutnya dilakukan pengujian (testing) dengan proses pengujian white box testing, black box testing, dan pengujian usability. Setelah semua proses selesai tahap selanjutnya dokumentasi dan pembuatan laporan.

\section{HASIL DAN PEMBAHASAN}

\section{Studi Kelayakan}

Studi kelayakan dilakukan untuk mendapatkan evaluasi dari mahasiswa sebagai user pengguna perpustakaan Sekolah Tinggi Teknologi Dumai terhadap sistem perpustakaan yang ada saat ini. Data yang terkumpul dari studi kelayakan dapat dijadikan sebagai sumber untuk perancangan aplikasi selanjutnya. Sampel yang diambil berjumlah 100 responden dengan status mahasiswa atau user perpustakaan. Pengambilan data dilakukan mahasiswa dengan mengisi survey online berupa form online yang dapat diakses mahasiswa dimana saja. Data yang sudah terkumpul diolah menggunakan skala likert dari 1 sampai 5.

Indikator instrumen yang diisi oleh mahasiswa pada pertanyaan 1 dan 2 diharapkan kurang dari $40 \%$ sesuai skala likert. Pada pertanyaan 1 dan 2 merujuk pada penilaian pelayanan sistem perpustakaan yang ada saaat ini. Sedangkan ketentuan 
instrumen pada pertanyaan 3 sampai 10 di harapkan lebih dari $40 \%$ sesuai skala likert. Pertanyaan 3 sampai 10 merupakan penilaian pengembangan sistem perpustakaan dari sistem sebelumnya. Perhitungan skala likert dapat dilakukan menggunakan rumusan sebagai berikut.

Skala Likert $(\%)=\frac{(S N \times 1)+(N \times 2)+(C \times 3)+(P \times 4)+(S P \times 5)}{\text { Jumla h sampel } \times 5} \times 100 \%$

Ketentuan:

$\mathrm{SN}=$ Skala Sangat Negatif

$\mathrm{N}=$ Skala Negatif

$\mathrm{C}=$ Skala Cukup

$\mathrm{P}=$ Skala Positif

$\mathrm{SP}=$ Skala Sangat Positiuf

Tabel 1. Studi Kelayakan Sistem

\begin{tabular}{|c|l|c|c|c|c|c|c|}
\hline No & \multicolumn{1}{|c|}{ Pertanyaan } & SN & N & C & P & SP \\
\hline Kelayakan sistem saat ini & 55 & 20 & 10 & 15 & 0 \\
\hline 1 & $\begin{array}{l}\text { Apakah pencarian pustaka di perpustakaan } \\
\text { saat ini mudah dilakukan? }\end{array}$ & 60 & 20 & 10 & 10 & 0 \\
\hline 2 & $\begin{array}{l}\text { Apakah proses peminjaman dan } \\
\text { pengembalian pustaka saat ini mudah } \\
\text { dilakukan? }\end{array}$ & \multicolumn{5}{|l|}{} \\
\hline Kelayakan pengembangan sistem & $\begin{array}{l}\text { Pencarian pustaka akan menjadi lebih mudah } \\
\text { jika menggunakan smartphone? }\end{array}$ & 0 & 0 & 0 & 0 & 100 \\
\hline 4 & $\begin{array}{l}\text { Apakah perlu penambahan fitur pelayanan } \\
\text { perpustakaan? }\end{array}$ & 0 & 0 & 0 & 0 & 100 \\
\hline 5 & $\begin{array}{l}\text { Apakah anda setuju adanya fitur pencarian } \\
\text { pustaka melalui scan barcode? }\end{array}$ & 0 & 0 & 0 & 20 & 80 \\
\hline 6 & $\begin{array}{l}\text { Apakah anda setuju mahasiswa dapat } \\
\text { memesan pustaka untuk dipinjam? }\end{array}$ & 0 & 0 & 10 & 20 & 70 \\
\hline 7 & $\begin{array}{l}\text { Apakah fitur informasi pustaka terbaru dan } \\
\text { terlaris dibutuhkan? }\end{array}$ & 0 & 0 & 10 & 30 & 60 \\
\hline 8 & $\begin{array}{l}\text { Apakah informasi histori peminjaman } \\
\text { anggota dibutuhkan? }\end{array}$ & 0 & 0 & 20 & 30 & 50 \\
\hline 9 & $\begin{array}{l}\text { Apakah informasi histori peminjam pustaka } \\
\text { dibutuhkan? }\end{array}$ & 0 & 0 & 25 & 20 & 55 \\
\hline 10 & $\begin{array}{l}\text { Apakah perlu informasi letak pustaka } \\
\text { ditunjukkan melalui denah rak di } \\
\text { perpustakaan? }\end{array}$ & 0 & 0 & 0 & 30 & 70 \\
\hline
\end{tabular}


Tabel 2. Perhitungan skala Likert

\begin{tabular}{|c|c|c|}
\hline No & Rumus & Presentase \\
\hline 1 & $\frac{(55 \times 1)+(20 \times 2)+(10 \times 3)+(15 \times 4)+(0 \times 5)}{100 \times 5} \times 100 \%$ & $37 \%$ \\
\hline 2 & $\frac{(60 \times 1)+(20 \times 2)+(10 \times 3)+(10 \times 4)+(0 \times 5)}{100 \times 5} \times 100 \%$ & $34 \%$ \\
\hline 3 & $\frac{(0 \times 1)+(0 \times 2)+(0 \times 3)+(0 \times 4)+(100 \times 5)}{100 \times 5} \times 100 \%$ & $100 \%$ \\
\hline 4 & $\frac{(0 \times 1)+(0 \times 2)+(0 \times 3)+(0 \times 4)+(100 \times 5)}{100 \times 5} \times 100 \%$ & $100 \%$ \\
\hline 5 & $\frac{(0 \times 1)+(0 \times 2)+(0 \times 3)+(20 \times 4)+(80 \times 5)}{100 \times 5} \times 100 \%$ & $96 \%$ \\
\hline 6 & $\frac{(0 \times 1)+(0 \times 2)+(10 \times 3)+(20 \times 4)+(70 \times 5)}{100 \times 5} \times 100 \%$ & $92 \%$ \\
\hline 7 & $\frac{(0 \times 1)+(0 \times 2)+(10 \times 3)+(30 \times 4)+(60 \times 5)}{100 \times 5} \times 100 \%$ & $90 \%$ \\
\hline 8 & $\frac{(0 \times 1)+(0 \times 2)+(20 \times 3)+(30 \times 4)+(50 \times 5)}{100 \times 5} \times 100 \%$ & $86 \%$ \\
\hline 9 & $\frac{(0 \times 1)+(0 \times 2)+(25 \times 3)+(20 \times 4)+(55 \times 5)}{100 \times 5} \times 100 \%$ & $86 \%$ \\
\hline 10 & $\frac{(0 \times 1)+(0 \times 2)+(0 \times 3)+(30 \times 4)+(70 \times 5)}{100 \times 5} \times 100 \%$ & $94 \%$ \\
\hline
\end{tabular}

Hasil dari pengisian instrumen pertanyaan tentang sistem perpustakaan di Sekolah Tinggi Teknologi Dumai adalah:

a. Pada intrumen pertanyaan 1 diperoleh nilai $37 \%$ dan pertanyaan 2 diperoleh nilai $34 \%$.

b. Pada instrumen pertanyaan 3 diperoleh nilai $100 \%$, pertanyaan 4 diperoleh nilai $100 \%$, pertanyaan 5 diperoleh nilai 96\%, pertanyaan 6 diperoleh nilai $92 \%$, pertanyaan 7 diperoleh nilai $90 \%$, pertanyaan 8 diperoleh nilai $86 \%$, pertanyaan 9 diperoleh nilai $86 \%$, dan pertanyaan 10 diperoleh nilai $94 \%$.

Kesimpulan dari hasil penilaian instrument pertanyaan menujukkan bahwa sistem lama dibutuhkan pengembangan ke sistem berbasis mobile smartphone. Hal ini dibuktikan dengan indikator keberhasilan pertanyaan 1 dan 2 mendapat ratarata $35,5 \%$ dan pertanyaan 3 sampai 10 mendapat rata-rata $93 \%$.

\section{White box testing}

Tahapan pengujian White Box yang dilakukan peneliti adalah:

a. Menentukan notasi diagram alir

Notasi diagram alir dibawah ini merupakan notasi diagram alir aplikasi yang dibuat berdasarkan diagram alir aplikasi yang dikembangkan. Pada gambar dibawah ini node digambarkan sebagai lingkaran dengan angka didalamnya sedangkan edge digambarkan sebagai garis dengan anak panah yang menghubungkan antar node. 


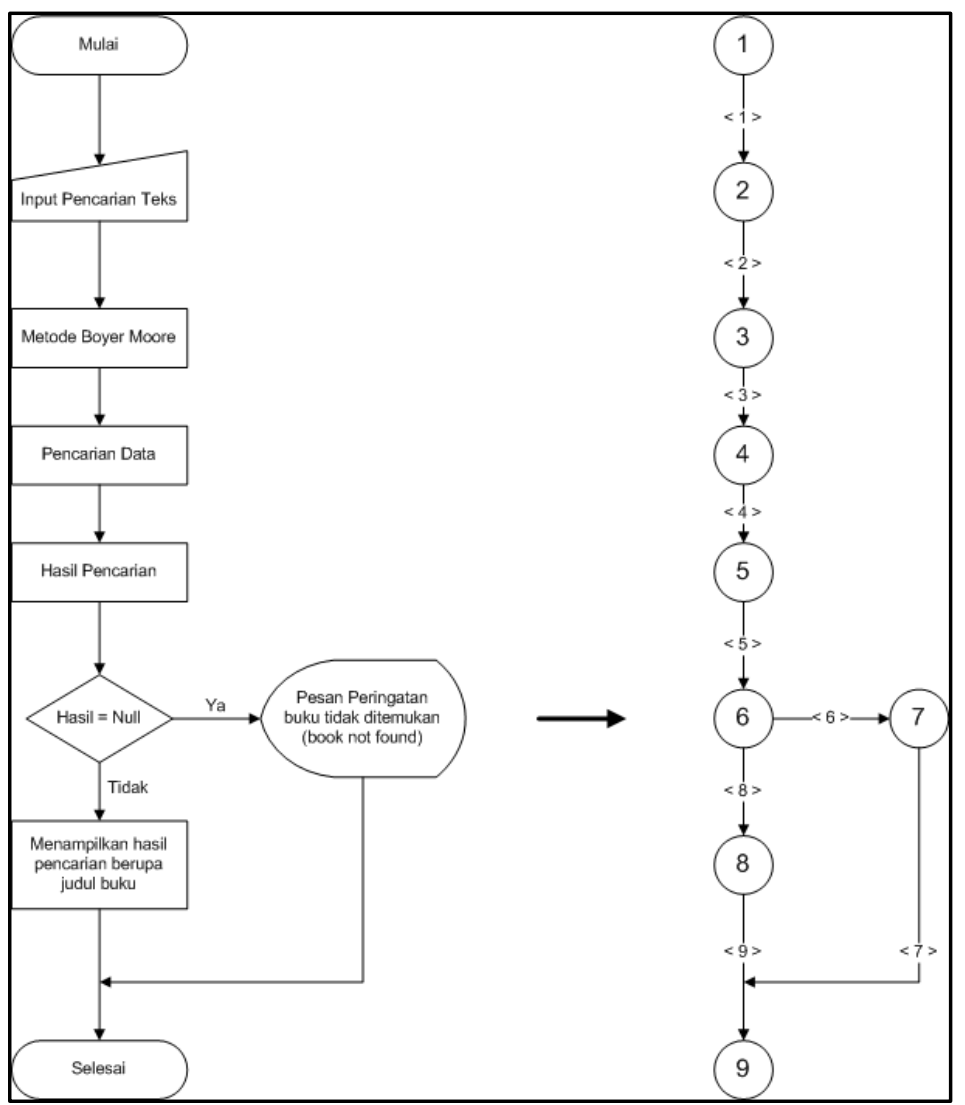

Gambar 2. Notasi Diagram Alir Proses Pencarian Judul Pustaka melalui Teks

Berdasarkan gambar 2 dapat diketahui jumlah edge ada 9 dan jumlah node ada 9. Seluruh node yang ditunjukkan pada gambar tersebut mewakili seluruh simbol pada diagram alir (flowchart) aplikasi. Simbol pada diagram alir menggambarkan setiap proses yang ada pada aplikasi.

b. Menghitung Cyclomatic Complexity

Menurut Pressman jika cyclomatic complexity digunakan dalam konteks metode pengujian basis path, maka nilai yang terhitung untuk cyclomatic complexity menentukan jumlah jalur independen dalam basis set suatu program. Persamaan cyclomatic complexity adalah:

Keterangan:

$$
\mathbf{V}(\mathbf{G})=\mathbf{E}-\mathbf{N}+\mathbf{2}
$$

V(G)= Jumlah cyclomatic complexity.

$\mathbf{E} \quad=$ Jumlah edge pada notasi diagram alir.

$\mathbf{N} \quad=$ Jumlah node pada notasi diagram alir.

Berdasarkan hasis analisis terhadap notasi diagram alir aplikasi pada gambar diatas, diketahui jumlah edge $(\mathrm{E})$ adalah 9 dan jumlah node $(\mathrm{N})$ adalah 9. Jumlah cyclomatic complexity adalah:

$\mathrm{V}(\mathrm{G})=9-9+2$

$\mathrm{V}(\mathrm{G})=2$

c. Menentukan test case

Hasil perhitungan terhadap cyclomatic complexityakan menentukan jumlah jalur independen basis set aplikasi. Hasil perhitungan cyclomatic complexity adalah 2. Jadi jumlah jalur independen pada aplikasi yang dikembangkan peneliti untuk pengujian white box adalah 2. Berdasarkan 
jumlah jalur independen tersebut maka dibuatlah test case untuk melakukan pengujian. Test case tersebut adalah:

1. Jalur $=1,2,3,4,5,6,7,9$

Test Case I

Test case ini terjadi ketika user melakukan pencarian judul pustaka yang ada di perpustakaan dengan menginputkan teks pada fasilitas pencarian teks. Pada test case ini hasil pencarian kata kunci judul pustaka dalam database tidak ditemukan.

2. Jalur $=1,2,3,4,5,6,8,9$

Test Case II

Test case ini terjadi ketika user melakukan pencarian judul pustaka yang ada di perpustakaan dengan menginputkan teks pada fasilitas pencarian teks. Pada test case ini hasil pencarian kata kunci judul pustaka dalam database ditemukan.

d. Pengujian test case

Hasil dari pengujian test case diatas adalah:

1. Test Case I

Pada pengujian test case I user memasukkan kata kunci pencarian data judul pustaka yang tidak terdapat dalam database perpustakaan sehingga hasil tidak ditemukan. Respon yang ditunjukkan aplikasi adalah memunculkan kotak dialog yang menyatakan bahwa pustaka tidak ditemukan (book not found). Berdasarkan hal tersebut dapat disimpulkan pengujian pada test case I sudah tercapai.

2. $\quad$ Test Case II

Pada pengujian test case II user memasukkan kata kunci pencarian data judul pustaka yang terdapat dalam database perpustakaan sehingga hasil ditemukan. Aplikasi akan memunculkan nama judul pustaka yang ditemukan berdasarkan input teks pencarian judul pustaka. Berdasarkan hal tersebut dapat disimpulkan pengujian test case II sudah tercapai.

Hasil pengujian test case secara lengkap ditunjukkan oleh tabel di bawah ini.

Tabel 3. Hasil pengujian test case aplikasi

\begin{tabular}{|c|c|c|c|c|c|c|c|c|c|c|}
\hline No & \multicolumn{9}{|c|}{ Test Case } & \multicolumn{2}{|c|}{ Ketercapaian } \\
\cline { 5 - 11 } & \multicolumn{1}{|c|}{ Ya } & Tidak \\
\hline 1. & 1 & 2 & 3 & 4 & 5 & 6 & 7 & 9 & $\sqrt{ }$ & \\
\hline 2. & 1 & 2 & 3 & 4 & 5 & 6 & 8 & 9 & $\sqrt{ }$ & \\
\hline
\end{tabular}

Hasil pengujian white box pada tabel diatas menggunakan metode basis path testing menunjukkan seluruh test case berhasil dieksekusi minimal satu kali. Berdasarkan hasil tersebut dapat disimpulkan bahwa aplikasi ini lolos pada pengujian white box.

\section{Black box testing}

Hasil pengujian sistem (black box testing) pada sistem informasi perpustakaan berbasis mobile di Sekolah Tinggi Teknologi Dumai adalah sebagai berikut: 
Tabel 4. Black Box Testing

\begin{tabular}{|c|c|c|c|c|}
\hline Interface & Yang diuji & Input & Output & Status \\
\hline \multirow[t]{2}{*}{ Menu Home } & Tab Terbaru & $\begin{array}{l}\text { Klik tab } \\
\text { terbaru }\end{array}$ & $\begin{array}{l}\text { Menampilkan nama } \\
\text { pustaka terbaru sesuai } \\
\text { dengan urutan input } \\
\text { nama pustaka. }\end{array}$ & Benar \\
\hline & Tab Populer & $\begin{array}{l}\text { Klik tab } \\
\text { populer }\end{array}$ & $\begin{array}{l}\text { Menampilkan nama } \\
\text { pustaka } \\
\text { terpopuler/terlaris } \\
\text { berdasarkan rating yang } \\
\text { dipilih oleh anggota } \\
\text { pada tampilan detail } \\
\text { pustaka. }\end{array}$ & Benar \\
\hline \multirow[t]{2}{*}{ Menu Login } & \multirow[t]{2}{*}{$\begin{array}{l}\text { Tombol login } \\
\text { diklik }\end{array}$} & $\begin{array}{l}\text { NIM : } \\
12510256 \\
\text { Password : } \\
12345\end{array}$ & User Login & Benar \\
\hline & & $\begin{array}{l}\text { NIM } \\
\text { (tidak } \\
\text { diisi) } \\
\text { Password : } \\
\text { (tidak } \\
\text { diisi) }\end{array}$ & $\begin{array}{l}\text { Muncul tanda warning } \\
\text { pada bagian samping } \\
\text { kanan box NIM dan jika } \\
\text { di klik maka akan } \\
\text { muncul pesan } \\
\text { "Masukkan NIM atau } \\
\text { email yang valid" } \\
\text { Muncul tanda warning } \\
\text { pada bagian samping } \\
\text { kanan box password dan } \\
\text { jika di klik maka akan } \\
\text { muncul pesan "Kolom } \\
\text { wajib diisi" }\end{array}$ & Benar \\
\hline \multirow[t]{3}{*}{$\begin{array}{l}\text { Fitur } \\
\text { pencarian } \\
\text { pustaka } \\
\text { melalui } \\
\text { teks }\end{array}$} & \multirow[t]{3}{*}{$\begin{array}{l}\text { Fitur } \\
\text { pencarian } \\
\text { teks }\end{array}$} & $\begin{array}{l}\text { Teks : } \\
\text { panduan } \\
\text { Tab } \\
\text { pilihan : } \\
\text { Judul }\end{array}$ & $\begin{array}{l}\text { Akan muncul judul } \\
\text { pustaka yang } \\
\text { mempunyai kata input } \\
\text { "panduan" }\end{array}$ & Benar \\
\hline & & $\begin{array}{l}\text { Teks : } \\
\text { panduan } \\
\text { Tab } \\
\text { pilihan : } \\
\text { Penulis }\end{array}$ & $\begin{array}{l}\text { Akan muncul tanda } \\
\text { bahwa pustaka tidak } \\
\text { tersedia (book not found) } \\
\text { karena sistem tidak } \\
\text { menemukan kata } \\
\text { panduan dalam pilihan } \\
\text { penulis. }\end{array}$ & Benar \\
\hline & & $\begin{array}{l}\text { Teks : } \\
\text { panduan } \\
\text { Tab } \\
\text { pilihan : } \\
\text { Penerbit }\end{array}$ & $\begin{array}{l}\text { Akan muncul tanda } \\
\text { bahwa pustaka tidak } \\
\text { tersedia (book not found) } \\
\text { karena sistem tidak } \\
\text { menemukan kata } \\
\text { panduan dalam pilihan } \\
\text { penerbit. }\end{array}$ & Benar \\
\hline
\end{tabular}




\begin{tabular}{|c|c|c|c|c|}
\hline $\begin{array}{l}\text { Fitur } \\
\text { pencarian } \\
\text { pustaka } \\
\text { melalui } \\
\text { Scan } \\
\text { Barcode }\end{array}$ & $\begin{array}{l}\text { Fitur } \\
\text { pencarian } \\
\text { Scan } \\
\text { Barcode }\end{array}$ & $\begin{array}{l}\text { Scan } \\
\text { Barcode } \\
\text { pustaka } \\
\text { yang telah } \\
\text { tersedia di } \\
\text { perpustak } \\
\text { aan Scan } \\
\text { Barcode } \\
\text { pustaka } \\
\text { yang tidak } \\
\text { tersedia di } \\
\text { perpustak } \\
\text { aan } \\
\end{array}$ & $\begin{array}{l}\text { Pada tampilan Search } \\
\text { Result akan muncul } \\
\text { nama pustaka yang } \\
\text { dicari scan barcode. } \\
\text { Pada tampilan Search } \\
\text { Result akan muncul } \\
\text { tanda bahwa pustaka } \\
\text { tidak tersedia (book not } \\
\text { found) karena sistem } \\
\text { tidak menemukan } \\
\text { barcode pustaka di } \\
\text { dalam database sistem. }\end{array}$ & Benar \\
\hline \multirow[t]{2}{*}{$\begin{array}{l}\text { Menu } \\
\text { Kategori } \\
\text { pustaka }\end{array}$} & $\begin{array}{l}\text { Tampilan } \\
\text { nama } \\
\text { pustaka } \\
\text { berdasarkan } \\
\text { kategori }\end{array}$ & $\begin{array}{l}\text { Klik menu } \\
\text { kategori } \\
\text { pustaka }\end{array}$ & $\begin{array}{l}\text { Menampilkan nama } \\
\text { pustaka berdasarkan } \\
\text { kategori pustaka }\end{array}$ & Benar \\
\hline & $\begin{array}{l}\text { Pilihan } \\
\text { Lihat Semua } \\
\text { pada } \\
\text { kategori } \\
\text { pustaka } \\
\text { yang dipilih }\end{array}$ & $\begin{array}{l}\text { Klik } \\
\text { pilihan } \\
\text { semua }\end{array}$ & $\begin{array}{l}\text { Menampilkan semua } \\
\text { nama pustaka } \\
\text { berdasarkan kategori } \\
\text { yang dipilih. }\end{array}$ & Benar \\
\hline $\begin{array}{l}\text { Menu } \\
\text { Peminjama } \\
\mathrm{n}\end{array}$ & $\begin{array}{l}\text { Menampilka } \\
\mathrm{n} \text { pustaka } \\
\text { yang } \\
\text { dipinjam }\end{array}$ & $\begin{array}{l}\text { Klik menu } \\
\text { peminjam } \\
\text { an }\end{array}$ & $\begin{array}{l}\text { Menampilkan semua } \\
\text { pustaka yang sedang } \\
\text { dipinjam (status pinjam) } \\
\text { oleh anggota. }\end{array}$ & Benar \\
\hline \multirow[t]{5}{*}{$\begin{array}{l}\text { Menu } \\
\text { Pemesanan }\end{array}$} & $\begin{array}{l}\text { Menampilka } \\
\mathrm{n} \text { pustaka } \\
\text { yang dipesan }\end{array}$ & $\begin{array}{l}\text { Klik menu } \\
\text { pemesana } \\
\mathrm{n}\end{array}$ & $\begin{array}{l}\text { Menampilkan semua } \\
\text { pustaka yang sedang } \\
\text { dipesan (status waiting) } \\
\text { oleh anggota. }\end{array}$ & Benar \\
\hline & $\begin{array}{l}\text { Tombol } \\
\text { pilihan pada } \\
\text { daftar } \\
\text { pustaka yang } \\
\text { dipesan }\end{array}$ & $\begin{array}{l}\text { Klik pada } \\
\text { tombol } \\
\text { pilihan }\end{array}$ & $\begin{array}{l}\text { Menampilkan daftar } \\
\text { pilihan hapus dan } \\
\text { history. }\end{array}$ & Benar \\
\hline & $\begin{array}{l}\text { Pilihan } \\
\text { hapus pada } \\
\text { daftar } \\
\text { pustaka } \\
\text { yang } \\
\text { dipesan } \\
\end{array}$ & $\begin{array}{l}\text { Klik } \\
\text { pilihan } \\
\text { hapus }\end{array}$ & $\begin{array}{l}\text { Menghapus nama } \\
\text { pustaka dalam daftar } \\
\text { pemesanan }\end{array}$ & Benar \\
\hline & $\begin{array}{l}\text { Pilihan } \\
\text { history }\end{array}$ & $\begin{array}{l}\text { Klik } \\
\text { pilihan } \\
\text { history }\end{array}$ & $\begin{array}{l}\text { Menampilkan history } \\
\text { pustaka berisi nama } \\
\text { anggota yang pernah } \\
\text { meminjam nama } \\
\text { pustaka. }\end{array}$ & Benar \\
\hline & $\begin{array}{l}\text { Detail } \\
\text { pustaka }\end{array}$ & $\begin{array}{l}\text { Klik pada } \\
\text { nama } \\
\text { pustaka }\end{array}$ & $\begin{array}{l}\text { Menampilkan detail } \\
\text { pustaka yang sedang } \\
\text { dipesan }\end{array}$ & Benar \\
\hline $\begin{array}{l}\text { Menu } \\
\text { History }\end{array}$ & $\begin{array}{l}\text { Menampilka } \\
\mathrm{n} \text { history }\end{array}$ & $\begin{array}{l}\text { Klik menu } \\
\text { history }\end{array}$ & $\begin{array}{l}\text { Menampilkan semua } \\
\text { pustaka yang pernah }\end{array}$ & Benar \\
\hline
\end{tabular}

UNITEX Vol 11 No.1 Januari - Juni 2018

\begin{tabular}{r|r} 
p-ISSN 2089- & e-ISSN \\
3957 & $2580-2585$
\end{tabular}




\begin{tabular}{|c|c|c|c|c|}
\hline \multirow[t]{3}{*}{$\begin{array}{l}\text { Peminjama } \\
\mathrm{n}\end{array}$} & $\begin{array}{l}\text { peminjaman } \\
\text { anggota }\end{array}$ & $\begin{array}{l}\text { peminjam } \\
\text { an }\end{array}$ & $\begin{array}{l}\text { anggota pinjam pada } \\
\text { daftar history pustaka } \\
\text { dengan status } \\
\text { peminjaman kembali. }\end{array}$ & \\
\hline & $\begin{array}{l}\text { Menampilka } \\
\text { n detail } \\
\text { pustaka }\end{array}$ & $\begin{array}{l}\text { Klik } \\
\text { daftar } \\
\text { judul } \\
\text { buku }\end{array}$ & $\begin{array}{l}\text { Menampilkan detail } \\
\text { pustaka yang pernah } \\
\text { anggota pinjam . }\end{array}$ & Benar \\
\hline & $\begin{array}{l}\text { Menampilka } \\
\text { n history } \\
\text { pustaka }\end{array}$ & $\begin{array}{l}\text { Klik pada } \\
\text { pilihan } \\
\text { history }\end{array}$ & $\begin{array}{l}\text { Menampilkan history } \\
\text { pustaka berisi semua } \\
\text { nama anggota yang } \\
\text { pernah meminjam } \\
\text { pustaka tersebut. }\end{array}$ & Benar \\
\hline $\begin{array}{l}\text { Menu } \\
\text { syarat dan } \\
\text { ketentuan }\end{array}$ & $\begin{array}{l}\text { Menampilka } \\
\text { n syarat dan } \\
\text { ketentuan }\end{array}$ & $\begin{array}{l}\text { Klik menu } \\
\text { syarat dan } \\
\text { ketentuan }\end{array}$ & $\begin{array}{l}\text { Menampilkan beberapa } \\
\text { syarat dan ketentuan } \\
\text { yang berlaku untuk } \\
\text { peminjaman pustaka }\end{array}$ & Benar \\
\hline \multirow[t]{3}{*}{$\begin{array}{l}\text { Menu } \\
\text { notifikasi }\end{array}$} & $\begin{array}{l}\text { Menampilka } \\
\text { n notifikasi }\end{array}$ & $\begin{array}{l}\text { Klik menu } \\
\text { notifikasi }\end{array}$ & $\begin{array}{l}\text { Menampilkan seluruh } \\
\text { notifikasi berkaitan } \\
\text { dengan peminjaman, } \\
\text { pemesanan, dan pustaka } \\
\text { terbaru }\end{array}$ & Benar \\
\hline & $\begin{array}{l}\text { Tanda } \\
\text { notifikasi } \\
\text { sudah dilihat }\end{array}$ & $\begin{array}{l}\text { Klik } \\
\text { notifikasi } \\
\text { yang ada } \\
\text { dalam } \\
\text { daftar } \\
\end{array}$ & $\begin{array}{l}\text { Menampilkan detail } \\
\text { pustaka dan akan diberi } \\
\text { tanda checklist pada } \\
\text { daftar notifikasi jika } \\
\text { sudah dilihat. }\end{array}$ & Benar \\
\hline & $\begin{array}{l}\text { Tanda } \\
\text { notifikasi } \\
\text { belum } \\
\text { dilihat }\end{array}$ & - & $\begin{array}{l}\text { Pada menu notifikasi } \\
\text { akan terlihat tanda } \\
\text { jumlah notifikasi yang } \\
\text { belum dilihat dan daftar } \\
\text { notifikasi belum ada } \\
\text { tanda checklist atau } \\
\text { notifikasi masih } \\
\text { berbentuk tulisan tebal } \\
(\text { bold }) \text {. }\end{array}$ & Benar \\
\hline $\begin{array}{l}\text { Menu } \\
\text { setelan }\end{array}$ & $\begin{array}{l}\text { Menampilka } \\
\mathrm{n} \text { filter } \\
\text { pustaka } \\
\text { terbaru }\end{array}$ & $\begin{array}{l}\text { Klik menu } \\
\text { setelan }\end{array}$ & $\begin{array}{l}\text { Menampilkan filter } \\
\text { pustaka terbaru yang } \\
\text { akan anggota ikuti } \\
\text { berdasarkan kategori } \\
\text { pustaka yang dipilih } \\
\text { dengan cara memberi } \\
\text { tanda checklist pada } \\
\text { checkbox yang tersedia. }\end{array}$ & Benar \\
\hline $\begin{array}{l}\text { Menu } \\
\text { tentang } \\
\text { aplikasi }\end{array}$ & $\begin{array}{l}\text { Menampilka } \\
\text { n versi } \\
\text { aplikasi }\end{array}$ & $\begin{array}{l}\text { Klik menu } \\
\text { tentang } \\
\text { aplikasi }\end{array}$ & $\begin{array}{l}\text { Menampilkan versi } \\
\text { aplikasi yang di install } \\
\text { oleh anggota. }\end{array}$ & Benar \\
\hline $\begin{array}{l}\text { Menu } \\
\text { keluar }\end{array}$ & $\begin{array}{l}\text { Keluar dari } \\
\text { login anggota }\end{array}$ & $\begin{array}{l}\text { Klik menu } \\
\text { keluar }\end{array}$ & $\begin{array}{l}\text { Mengeluarkan login } \\
\text { anggota dari aplikasi. }\end{array}$ & Benar \\
\hline $\begin{array}{l}\text { Menekan } \\
\text { tombol back } \\
\text { pada } \\
\text { tampilan }\end{array}$ & $\begin{array}{l}\text { Menampilka } \\
\mathrm{n} \text { perintah } \\
\text { untuk keluar } \\
\text { aplikasi }\end{array}$ & $\begin{array}{l}\text { Klik } \\
\text { tombol } \\
\text { back }\end{array}$ & $\begin{array}{l}\text { Menampilkan "Tekan } \\
\text { lagi untuk keluar" untuk } \\
\text { keluar dari aplikasi } \\
\text { tanpa harus keluar login }\end{array}$ & Benar \\
\hline
\end{tabular}




\begin{tabular}{|l|l|l|l|}
\hline awal & $\begin{array}{l}\text { tanpa keluar } \\
\text { login anggota }\end{array}$ & $\begin{array}{l}\text { anggota. Sehingga saat } \\
\text { anggota membuka } \\
\text { aplikasi secara otomatis } \\
\text { anggota masih berstatus } \\
\text { login. }\end{array}$ & \\
\hline
\end{tabular}

\section{Pengujian Usability}

Pengujian usability dilakukan dengan berbagai aspek usability, yaitu aspek learnability, flexibility, effectiveness dan attitude. Hasil pengujian terhadap 100 responden yang disajikan secara berurutan oleh tabel 5 , tabel 6 , tabel 7 , dan tabel 8 yang berisi 35 pertanyaan dikelompokkan pada tiap aspek usability berikut:

Tabel 5. Aspek Learnability

\begin{tabular}{|c|c|}
\hline Pernyataan & Nilai \\
\hline $\begin{array}{l}\text { 1. Aplikasi ini mempermudah dalam menyelesaikan apa yang ingin saya } \\
\text { selesaikan }\end{array}$ & 98 \\
\hline 2. Aplikasi ini mudah dipelajari bagaimana penggunaannya & 96 \\
\hline 3. Aplikasi ini memberikan informasi pustaka terbaru & 100 \\
\hline 4. Aplikasi ini memberikan informasi pustaka terpopuler & 100 \\
\hline 5. Aplikasi ini memberikan informasi pustaka sejenis & 100 \\
\hline 6. Aplikasi ini memberikan informasi history peminjam pustaka & 100 \\
\hline 7. Aplikasi ini memberikan informasi history peminjaman anggota & 100 \\
\hline 8. Aplikasi ini memberikan informasi stok pustaka & 100 \\
\hline 9. Aplikasi ini memberikan informasi rating pustaka & 100 \\
\hline 10. Aplikasi ini memberikan akses anggota inputrating pustaka & 100 \\
\hline 11. Aplikasi ini memberikan informasi letak pustaka & 92 \\
\hline 12. Pencarian pustaka melalui teks mudah digunakan & 100 \\
\hline 13. Pencarian pustaka melalui scanbarcode mudah digunakan & 94 \\
\hline 14. Fitur pemesanan pustaka mudah digunakan & 90 \\
\hline 15. Proses pemesanan pustaka lebih mudah dan cepat & 96 \\
\hline 16. Proses peminjaman pustaka lebih mudah dan cepat & 94 \\
\hline 17. Aplikasi memberikan notifikasi yang sesuai & 96 \\
\hline 18. Aplikasi ini mudah dipahami dan digunakan & 98 \\
\hline Aplikasi ini praktis digunakan & \\
\hline
\end{tabular}

Tabel 6. Aspek Flexibility

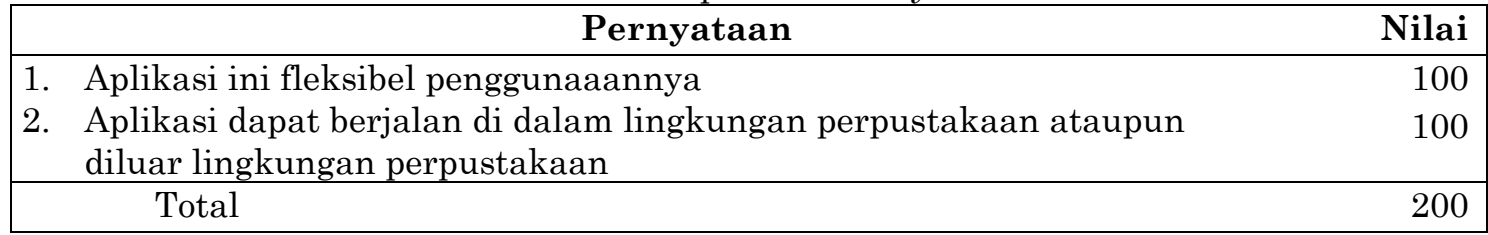

Tabel 7. Aspek Effectiveness

Pernyataan Nilai

1. Aplikasi ini membantu saya bekerja lebih efektif 94

2. Aplikasi ini menghemat waktu ketika saya menggunakannya 90

3. Aplikasi ini membutuhkan langkah yang sedikit untuk mencapai apa 100 $\begin{array}{ll}\text { yang ingin saya lakukan dengan aplikasi ini } & 100\end{array}$

4. Form menu login memberikan pemberitahuan jika username dan 
password tidak diisi atau tidak sesuai

5. Tidak membutuhkan waktu yang lama untuk membuka aplikasi 92

6. Tidak membutuhkan waktu yang lama untuk akses pencarian 96 pustaka melalui scanbarcode

7. Aplikasi memberikan respon dengan baik untuk setiap aktifitas yang dikerjakan.

Tabel 8. Aspek Attitude

Pernyataan

Nilai

1. Aplikasi ini sesuai dengan kebutuhan saya

2. Aplikasi ini melakukan sesuai dengan yang saya harapkan untuk dilakukan

3. Aplikasi ini bekerja seperti yang saya inginkan

4. Aplikasi ini memiliki tampilan yang user friendly

5. Aplikasi ini sangat berguna

6. Saya dapat menggunakan aplikasi ini tanpa panduan tertulis

7. Saya puas menggunakan aplikasi ini

Perhitungan presentase dari berbagai aspek usability apat menggunakan rumus berikut:

Aspek Usability $=\frac{\text { Total Nilai Aspek Usability }}{\text { Jumla h Pernyataan } \times 100} \times 100 \%$

1. Aspek Learnability

2. Aspek Flexibility

$$
\frac{1857}{19 \times 100} \times 100 \%=\frac{1857}{1900} \times 100 \%=0,9757 \times 100 \%=97,57 \%
$$

$$
\frac{200}{2 \times 100} \times 100 \%=\frac{200}{200} \times 100 \%=100 \%
$$

3. Aspek Effectiveness

4. Aspek Attitude

$$
\frac{662}{7 \times 100} \times 100 \%=\frac{662}{700} \times 100 \%=0,9457 \times 100 \%=94,57 \%
$$

$$
\frac{652}{7 \times 100} \times 100 \%=\frac{652}{700} \times 100 \%=0,9314 \times 100 \%=93,14 \%
$$

Hasil perhitungan rerata dari masing-masing aspek usability didapatkan berdasarkan pembagian jumlah nilai tiap aspek yang diukur dengan jumlah pernyataan. Hasil perhitungan disajikan untuk masing-masing aspek usability pada tabel 9 berikut: 
Tabel 9. Rerata hasil pengujian usability

\begin{tabular}{|c|c|c|c|}
\hline $\begin{array}{c}\text { Learnabilit } \\
\mathbf{y}\end{array}$ & $\begin{array}{c}\text { Flexibilit } \\
\mathbf{y}\end{array}$ & $\begin{array}{c}\text { Effectivenes } \\
\mathbf{s}\end{array}$ & $\begin{array}{c}\text { Attitud } \\
\mathbf{e}\end{array}$ \\
\hline $97,57 \%$ & $100 \%$ & $94,57 \%$ & $93,14 \%$ \\
\hline
\end{tabular}

Rumus usability:

Usability $(\%)=\frac{A+B+C+D}{4} \times 100 \%$

$\mathrm{A}=$ Presentasi nilai learnability

$\mathrm{B}=$ Presentasi nilai flexibility

$\mathrm{C}=$ Presentasi nilai effectiveness

$\mathrm{D}=$ Presentasi nilai attitude

Usability $(\%)=\frac{97,57+100+94,57+93,14}{4 \times 100} \times 100 \%$

Usability $(\%)=\frac{385,28}{400} \times 100 \%=0.9632 \times 100 \%=96.32 \%$

Pengukuran nilai pengujian usability menunjukkan bahwa keseluruhan aspek yang diukur mencapai nilai usability yang tinggi yaitu 96,32\%. Hal ini berarti bahwa sistem informasi perpustakaan berbasis mobile layak dan dapat digunakan (usable) dengan baik.

\section{KESIMPULAN}

Berdasarkan hasil pengujian dari Rancang Bangun Sistem Informasi Perpustakaan Berbasis Mobile Pada Sekolah Tinggi Teknologi Dumai maka dapat disimpulkan sebagai berikut:

a. Hasil penilaian instrument pertanyaan menujukkan bahwa sistem lama dibutuhkan pengembangan ke sistem berbasis mobile smartphone. Hal ini dibuktikan dengan indikator keberhasilan pertanyaan 1 dan 2 mendapat ratarata $35,5 \%$ dan pertanyaan 3 sampai 10 mendapat rata-rata $93 \%$.

b. Hasil pengujian white box pada perancangan sistem informasi perpustakaan berbasis mobile menggunakan metode basis path testing menunjukkan seluruh test case berhasil dieksekusi minimal satu kali.

c. Pengukuran nilai pengujian usability menunjukkan bahwa keseluruhan aspek yang diukur mencapai nilai usability yang tinggi yaitu $96,32 \%$. Hal ini berarti bahwa sistem informasi perpustakaan berbasis mobile layak dan dapat digunakan (usable) dengan baik.

\section{SARAN}

Saran Rancang Bangun Sistem Informasi Perpustakaan Berbasis Mobile Pada Sekolah Tinggi Teknologi Dumai sangat mungkin untuk ditingkatkan lagi pada penelitian selanjutnya seperti:

a. Pada penelitian selanjutnya dapat dikembangkan dengan menggunakan metode pendekatan yang lain sebagai perbandingan dengan penelitian ini.

b. Pengembangan penelitian dapat dilakukan dengan menambah fasilitas yang diberikan oleh sistem kepada pengguna. 
c. Pada proses pencarian pustaka dapat dikembangkan dengan menggunakan metode pencarian lain untuk perbandingan dengan penelitian yang sudah ada.

\section{DAFTAR PUstaka}

Arifah, F. N., Rosidi, A., Fatta, H. A., Evaluasi Kepuasan Pelayanan Pengguna Aplikasi OPAC Perpustakaan STMIK AMIKOM Yogyakarta, Citec Journal, No. 1, Vol. 1, Hal 46-56.

Firmansyah, R., 2018, Usability Testing dengan USE Quisionnaire pada Aplikasi SIPOLIN Provinsi Jawa Barat: SWABUMI, No. 1, Vol. 6.

Ginting, G.L., 2014, Penerapan Algoritma Boyer Moore pada Aplikasi Pengajuan Judul Skripsi Berbasi Web, Informasi dan Teknologi Ilmiah (INTI), No. 1, Vol III.

Heryanto, A., Alas, M. S., 2014, Model Keputusan Decision Tree untuk Optimalisasi Pengadaan Obat di Apotek, Jurnal Konferensi Nasional Sistem Informasi (KNSI), No KNSI 2014-221

Osagi, S., 2015, Perancangan Sistem Informasi Absensi Sebagai Penunjang Pengambilan Keputusan Kepala Madrasah, skripsi, Jurusan Sistem Informasi, Sekolah Tinggi Manajemen Dan Ilmu Komputer Stmik Raharja, Tangerang.

Pressman, R. S., 2010, Rekayasa Perangkat Lunak Pendekatan Praktisi edisi 7, Yogyakarta ANDI Yogyakarta

Saputri, D. L., 2010, Knowledge Management Bagi Sistem Informasi Perpustakaan Universitas Gadjah Mada, http://ramosknowledge.files.wordpress.com/2010/01/knowledge-managementbagi-sistem-informasi-perpustakaan-universitas-gadjah-mada.doc diakses tanggal 17 Maret 2014

Saefullah, A., Nurhidayah, I., 2013, Aplikasi Pembayaran Sewa Studio Musik 99 BerbasisWeb, CSRID Journal, No. 1, Vol. 5, Hal 1-10.

\section{Biodata Penulis:}

Nama lengkap penulis adalah Sigit Setiyanto dengan tempat tanggal lahir Bengkalis, 06 september 1991 yang beralamat dusun 1 trimukti rt 001 rw 002 desa langsatpermai kecamatan bungaraya kabupaten siak provinsi Riau. Alamat email penulis adalah sigitsiak@gmail.com, tahun lulus 2012 bidang ilmu sistem informasi S1 STMIK AMIKOM Yogyakarta. 